\title{
Jak lidově na outdoorové vzdělávání v Jižní Americe?
}

\section{Jiří Kmínek}

\section{Envigogika 10 (3) - Informace/Information}

Publikováno/Published dne 26. 9. 2015

DOI: $\underline{10.14712 / 18023061.490}$

\begin{abstract}
Abstrakt
V Pucallpě na řece Ucayali existuje už 8 let "odpolední škola", jménem Imagion. Záměr této školy $\vee$ Peru není nahrazovat dětem základní vzdělání, nýbrž probouzet $v$ nich přizeň $\mathrm{k}$ divoké prírodě. Autor se svolením autora pana doktora Jana Dungela $z$ Vracova použivá přibližně 300 jeho excelentních obrazů divoké jihoamerické fauny. Jde o světově ojedinělá zobrazení, která nemají jenom naučnou hodnotu, nýbrž jsou i poetická. Obrazy jsou instalovány do labyrintu, který má asi 400 možných průchozích cest - jejich umístění napodobuje džungli. Děti bludištěm procházejí s průvodcem nebo s kamarády nebo samy, a učí se poznávat jednotlivé druhy. Ve škole se také hrají divadelní představení z velice bohaté amazonské mytologie. Celkově je tato "výuka" zaměřená mj. proti předsudkům, upovídanému spiritualismu a šamanismu. $V$ roce 2016 se tento projekt přestěhuje do jednoho půvabného města pod východním úpatím And, do horské džungle. $V$ Satipu pak nabídne asi 20 evropským učitelům slušné ubytování za režijní cenu na jakkoliv dlouhou dobu. A potom se zde bude trpělivě, roky budovat mezinárodní kampus Imagion pro environmentální i ostatní školství.
\end{abstract}

\section{Klíčová slova}

Neformální vzdělávání, základy ekologie, sociální vztahy, chudoba, Jižní Amerika

\begin{abstract}
There has been an "afternoon school" called Imagion in Pucallpa on the Ucayali River for the last 8 years. The goal of this school in Peru is not to substitute primary education, but to nurture a relationship to the wilderness. The author (with permission from Dr. Jan Dungel from Vracov) has used approximately 300 of his excellent paintings of wild South American fauna. These unique pictures have not only an educational value, but are also poetic. They are installed within a labyrinth which has about 400 possible paths through it - their placement imitates the jungle. Children go through the maze with a guide, with their friends or alone, and learn to recognize different species. They also put on theater performances in the school from the Amazon's very rich mythology. Overall, this "teaching" is directed, inter alia, against prejudice, gossipy spiritualism and shamanism. In 2016, the project will move to one charming town under the eastern foothills of the Andes mountains in the jungle. In Satipo it will offer decent accommodation at cost price to about 20 European teachers for any length of time. And then an international Imagion campus
\end{abstract}


for environmental and other types of schools will be patiently built there over a number of years.

\section{Key words}

Non-formal education, principles of ecology, social relationships, poverty, South America 
Ze studijních důvodů, jako celoživotní příznivec divoké prírody jsem nedávno autobusy jel trasu Brazílie, Rio de Janeiro - Peru, Pucallpa. Trasou - Rio de Janeiro, jižní pobřeží Brazílie, Jihovýchodní Brazílie, Paraguay, jihozápadní Brazílie, východní a severní nížinná Bolívie, středo západní Brazílie, jižní nížinné Peru, přes Andy do Limy a zpět přes Andy do Pucallpy, kde až dosud mám školu jménem Imagion pro děti školou povinné.

Ani už nejsem nijaký cestovatel, protože i protékání kilometrů se zají. Jenomže já jsem jel, protože jsem chtěl poznat brazilské a bolivijské pantanaly a přechodové ekosystémy mezi deštnými pralesy a suchými pralesy. Ale nejsem polykač kilometrů. Takoví cestovatelé se mi zdají spiše, když se potkáváme, a když mi vyprávějí, kde všude už byli a kam že to ještě musí, legrační. Vášeň pro věc ale mají, to se jim musí nechat. A obzvláště cestovatelky jsou úžasné, a je jich, osamělých na cestách, řekl bych i $20 \%$. Já jsem to ale jel pěkně pomalu, čtyři měsíce. Když nemáte peníze, ale umíte to, vyjde Vás to na asi 90 000,- Kč i s letenkou. Musíte ale znát jazyk (nikoliv angličtinu), sociální okolnosti, a nedělat chyby. Jižní Amerika, věru, není bezpečná.

Ted' tedy jenom pár mých environmentálních postřehů z první čtvrtiny mé cesty např́č Jižní Amerikou. Nebudu je ale rozebírat podrobně, abych neunavil.

Nejostřejší řez mezi divokou přírodou a tvrdou osídleností, kterou jsem kdy viděl, je v Rio de Janeiru. Vedle chodníku v mondénní čtvrtí Copacabana je zídka asi metr vysoká, a těsně za ní úplně neprostupná džungle. Sotva byste do ní zasunuli ruku po loket, jak je vegetace hustá. Není osídlena ani narkomany. Podle mého názoru nesou právě tyto kousky původního porostu, a je jich tam docela dost, dominantní podíl na vizuální poezii Rio de Janeira. Podstatně větší, než architektura. Jenomže: porovnáte li četnost medializace Rio de Janeirských pralesíků s četností článků o architektuře, je to tak 1 : 100 000. K mé mrzutosti.

Kvưli vysokým cenám, po čtyřech nocích na plážích v Riu, úprk do Sao Paula. Tedy ne, že by mne lákalo Sao Paulo poznávat. Podíváte li se na mapy, na každé saopaolské území velikosti Prahy přináleží park velikosti asi tři tenisových kurtů. Dále mi stačí údaj, že tam žije kolem 20000000 lidí. A rychle pryč. Říkám si, aniž bych si dělal nároky na znalosti z psychiatrie, zda, žít v takovém městě není v podstatě psychóza. Promiňte, Sao Paolané.

Přes noc autobusem do Ciudad del Este. V noci brazilská zemědělská krajina vyznívá výtvarně úplně stejně jako Polabská nížina někde mezi Brandýsem a Mělníkem. Jenom města jsou jiná. Je to neustále se opakující stereotyp: pumpa, panelák, banka, supermarket, tř́dička zrna a znovu dokola totéž. Ta města jsou mladá a bez kouzla.

Na vodopádech Iguazú, což je tiskárna na peníze gratis (400,-Kč vstupné), není environmentální výzkumný ústav, přesto, že tento ekosystém je světově ojedinělý. Celkem bezesporu tam je o čem bádat. Trvale je tam $100 \%$ vlhkost vzduchu a 90 decibelů hlučnost a už to samo o sobě je dosti třeskutý důvod k pokládání mnoha vědeckých otázek. Brazilci to ale nedělají, a to jim za zlé mám. Neodpustím si uštěpačnou poznámku: za měsíc zisků ze vstupného už by na luxusní výzkumy měli peněz dost. Jakou barvu tkaniček na botách má ten který fotbalista ten který den, to je ale to, co se probírá. Brazílie nebude mou oblíbenou zemí.

Postřehy ukončuji, přesto, že jich mám v zásobě dostatek. Bylo by toho ale moc najednou a tento článek má být o mých zkušenostech s outdoorovým vzděláváním v Peru.

Tedy: v Pucallpě na řece Ucayali mám už 8 let "odpolední školu", jménem Imagion. $\checkmark$ mém prípadě „odpolední škola” neznamená, že je nábožensky zaměřená, nýbrž naopak. 
Proti předsudkům, upovídanému spiritualismu a šamanismu. K mé lítosti, import rychlokvašených českých šamanů k nám do České republiky je podle mne již za pomyslnou hranicí prijiatelnosti. Mohl bych jmenovat, avšak vychování mi to nedovoluje. Takových proroků je plný internet. Tak se děje, k mému trvalému údivu, že pro své plevelné projevy mají sály naplněné k prasknutí. A jejich vyznavači, o kterých vlastně vůbec nevím, co že to vlastně vyznávají, těmto "znalcům” bohatě platí jejich další výjezdy za zdánlivým poznáním. A jejich pořady vysílá i Česká televize. Pokoušet se tomu kvalifikovaně oponovat, není ale práce jenom pro mne, nýbrž i pro vás, vážení akademičtí pracovníci, pedagogové, antropologové atd.

Záměr mé školy $v$ Peru není nahrazovat dětem základní vzdělání, nýbrž probouzet $v$ nich přízeň $k$ divoké prírodě. Mám, se svolením autora pana doktora Jana Dungela $z$ Vracova, k dispozici asi 300 jeho excelentních zobrazení divoké jihoamerické fauny. Ta jeho zobrazení jsou světově ojedinělá. Nemají jenom naučnou hodnotu, nýbrž jsou i poetická. Jsou to obdivuhodné práce a naštěstí jsou obdivovány. No a ty obrazy dětem všemožně instalujeme do labyrintu, který má asi 400 možných průchozích cest. Tak dětem napodobujeme džungli. A děti bludištěm procházejí s průvodcem nebo s kamarády nebo samy, a učí se poznávat jednotlivé druhy. Také ale hrajeme divadelní představení z velice bohaté amazonské mytologie. Větší nároky zatím nemám. Už takto je dostatek.

Já jsem ale líný chlap, a tak si práci ulehčuji tím, že průvodce dětem v bludišti a režii her zhusta přenechávám místním dívkám ve věku 12-15 let. Protože jsou šikovné, lépe než já ovládají španělštinu a jsou v prudkém vývoji. A vzniká nám tak plný, pěkný edukační a sociální řetězec: děti, dívky, mámy a potažmo tetičky, babičky atd. A tak o mém projektu ví široké okolí.

Pokud bychom ale $s$ aktivitami pro děti nezačali včas, $v$ útlém věku, je to bez naděje. Ve čtrnácti letech už se $v$ nich probouzí sexuální instinkt. A to už je pozdě. Diskotékovou mládež už bytostnou přízeň a odpovědnost $\mathrm{k}$ přírodě nenaučíme.

Subjektivně si myslím, že můj peruánský projekt je už dlouho v podstatě úspěšný a mámy dětí jsou zřejmě na mé straně. To je pro mne to nejdůležitější. Mohl bych hluboce rozebrat, proč jsou na mé straně. Jenomže, to by bylo na samostatný článek.

Ted' sdělím to první podstatné: protože asi $90 \%$ matek je $v$ Peru svými partnery opuštěno, je mateřství nesrovnatelně obtižnější než v Evropě. Děti běžně školu navštěvují jenom nahodile. To však není pouze sociokulturní zvyk, nýbrž věcná nemožnost denní docházky žáků do škol. Z těchto nesnází ale jasně vyplývá, že děti vyspívají extrémně nevyrovnaně. Některá zadání na mém projektu snadno vyřeší pětileté dítě, a čtrnáctileté nikoliv. Obecně ale platí, že evropské děti, které se v Peru mých her také účastní, jsou se znalostmi o mnoho napřed. To ale, prosím, nechápejte jako moji výhradu vůči amazonským dětem. Já jsem tam proto, abychom se sousedkami připravovali pro děti takové outdoorové edukační aktivity, které tyto rozdíly zmírňují.

Občas dětem za jejich výkony koupím bednu do celofánu balených sušenek, protože se po nich mohou "utlouci". Postaví se do fronty, já je zpřeházím, aby vepředu byly holky, a fasují. A v momentu, kdy ode mne sušenky prebírají, strhnou z nich divoce obaly a začnou si dávat "do nosíků". Jenomže já mám za chvíli na trávníku vrstvu celofánu. Ted' už je to lepší, ale návyk na to, aby po sobě obaly děti uklidily, tedy opravdu neměly. Bylo dosti pracné, než to začaly dělat bez poněkud nepřiměřeného naléhání z mé strany.

Píši o tom proto, že je málo známá skutečnost, že celofánové a mikrotenové obaly se velmi často dostanou vinou špatného odpadového hospodaření do řek. No a ryby, 
obojživelníci, plazi i ptáci často tyto plasty detekují jako shluk jiker a žerou je. Ztráty na populacích jsou těžko odhadnutelné, ale dozajista veliké. Viděl jsem docela dost drsných fotek zbytečně umírajících zvírat tímto způsobem. A někde asi $300 \mathrm{~km}$ pod Manausem po proudu, tam, kde už se tok Amazonky v podstatě zastaví, musí být u dna tohoto zázraku naší planety už tisíce tun tohoto těžko rozložitelného odpadu. Moje fantazie jako výtvarníka je dosti bujná a obrazivá. Mám z toho noční můry.

Dále, jednoduché počty: Je mi 60 let a $v$ dohledné době se ukázněně zařadím mezi dusíkaté, vápenaté a jiné sloučeniny ( $1 \mathrm{ks})$, s bezpečným výhledem na atomový důchod. Ale $v$ dětech, které se her na mém projektu již zúčastnily (asi 500 ks), nějaká znalost třeba zůstane, nebo zájem, a něco ve prospěch divoké prírody $z$ toho vyplyne. To měřit neumím, a proto neměřím.

Jdeme na to $s$ mými př́telkyněmi př́močaře a bez akademické přešlechtěnosti. Klukům na projektu třeba říkáme, že se na znalosti o zviřatech dobře balí holky. To je pravda a zabírá to. Reagují na to i chlapci ve věku 5 ti let. Je to vrozené. A je třeba to zkoušet, jak to jde.

Mám takové sveřepé pravidlo, které jsem se naučil zde u nás $v$ Čechách: mít vědomě rád atmosféru letního koupaliště. Mamky poslouchají rádio a vybalují svačiny, děti se cachtají. Už jenom zvukově je to velice př́jemný vjem. A na celém světě je stejný. Představte si to, prosím, určitě to znáte. Tak takovou atmosféru se na projektu snažíme udržovat. A daří se to.

Ale, i kdyby náš projekt ovlivnil třeba jenom dvě děti (a tento počet mám docela jistý, jsou to synové mých dvou prítelkyň), smysl mi to dává tak jako tak. Protože to už máme $2-1=1$. Alespoň tedy nulový př́růstek příznivců divoké prírody. Když ale jedeme $s$ těmito kluky $v$ sobotu ráno na trh, cestou očima hledají všemožnou zviřenu ve větvích stromů, ve vzduchu, na zemi i ve vodě. Bud' mi chtějí udělat radost, nebo jsou opravdu zvědaví. Obojí je správně.

Přesto, že si o mne mnozí myslí, že jsem pošetilec, je mi to zcela Ihostejné. Já dělám pro divokou amazonskou prírodu skrze děti alespoň něco, přímo "na ulici”. A po hrách na projektu mne sousedky zvou na anýzovou limonádu, nebo "trago de chuchuasi”, panáka fernetu podobného domácího likéru, což je od nich vždy milé. Tak udržujeme sociální soudržnost. Z mého pohledu toto celé plní to základní, proč tam jsem: alespoň trošku obracím na místní úrovni pozornost $\mathrm{k}$ tomu, že amazonská fauna vůbec existuje. To žádné teoretizování v posluchárnách vysokých škol nenahradí.

Dále to ted' nebudu rozebírat, protože českým čtenářům tohoto článku je hloubka indiference amazoňanů vůči divoké př́rodě nevysvětlitelná. To má úplně jiné sociokulturní dimenze, zde u nás $v$ Čechách i v Evropě celkově, nepochopitelné. Ted' to popisovat, by bylo plýtvání časem. To byste museli zažít.

Přinejmenším jsou mé aktivity v Peru globálně úplně nový pozitivní veřejný sociální jev, jehož jsem stoprocentním autorem. A to cíleně $v$ tom místě naší planety, kde je to podle mne nejvíce zapotřebí. $V$ této chvíli již předem vnímám údiv akademiků, jaký že jsem to nerozuma, že věci se neodvratně ději tak, jak se dějí. Vážení akademici: rád Vás čtu, poslouchám, jsem na Vás jako Čech hrdý, respektuji Vás. Avšak, měli byste už být účinnější, více na očích, s větším společenským dopadem.

Já pro ochranu Amazonie budu dále dělat tohle: $V$ roce 2016 můj projekt přestěhuji do jednoho půvabného města pod východním úpatím And, do horské džungle. Jednak se mi totiž v amazonských rovinách po Andách stýská, a také jsem už domluvený s paní 
bývalou starostkou tohoto města jménem Satipo, že pro můj projekt udělá maximum. $\checkmark$ Peru je třeba jednat jenom s dámami. Peruánští "machos" jsou na $95 \%$ opravdu $\mathrm{k}$ ničemu, avšak dámy jsou naprosto obdivuhodné a Ize jim věřit. Zkrátka mámy.

Záměr je takový, že $v$ Satipu nabídneme asi 20 ti evropským, především českým penzionovaným i aktivním učitelům slušné ubytování za režijní cenu na jakkoliv dlouhou dobu. A potom budeme trpělivě, roky budovat mezinárodní kampus Imagion pro environmentální i ostatní školství. Bude se aktivně relaxovat a spolupracovat s místními mámami, jejich dětmi a základní školou. Satipo je pro to optimální. $50 \mathrm{~km}$ do kopce jsou už šestitisícovky s ledovci, a $50 \mathrm{~km}$ opačným směrem už jsou velké nížinné řeky. Tedy všechny biotopy $v$ jednom chumlu. A inckých i předinckých památek pro hloubání o historii je tam také do sytosti. Hurá. Už se můžete směle i nesměle hlásit na organizování věci tady $u$ nás $v$ republice. Jasné obrysy už mám $v$ hlavě, takže konkrétním lidem mohu vysvětlovat konkrétní vize.

A na konec to druhé podstatné $v$ tomto mém neakademickém článku: $V$ Andách už jsou asi 1500 let zhotoveny miliony trvale úrodných terasových políček. Především se na nich pěstují brambory a quinua. Takže Kečuové a Aymarové už mají dosti dlouho splněno to, co je pro lidstvo podstatné. Důstojnost, soběstačnost a udržitelnost. Navíc jsou meze mezi políčky ideální niky pro kolibříky. Možná byste nevěřili, ale díky př́rodě a indiánům je jich tam pořád dost. Druhé hurá.

P.S. Naštěstí už Peruánci dobře vědí, že Amazonie je v mnoha ohledech výjimečná. Už je to $v$ nich pevně vrostlé. A díky prudkému ekonomickému růstu se už docela často stává, že děti autobusy vyrážejí navštěvovat džungli. Hurá. To bylo ještě před sedmi lety nemyslitelné. 


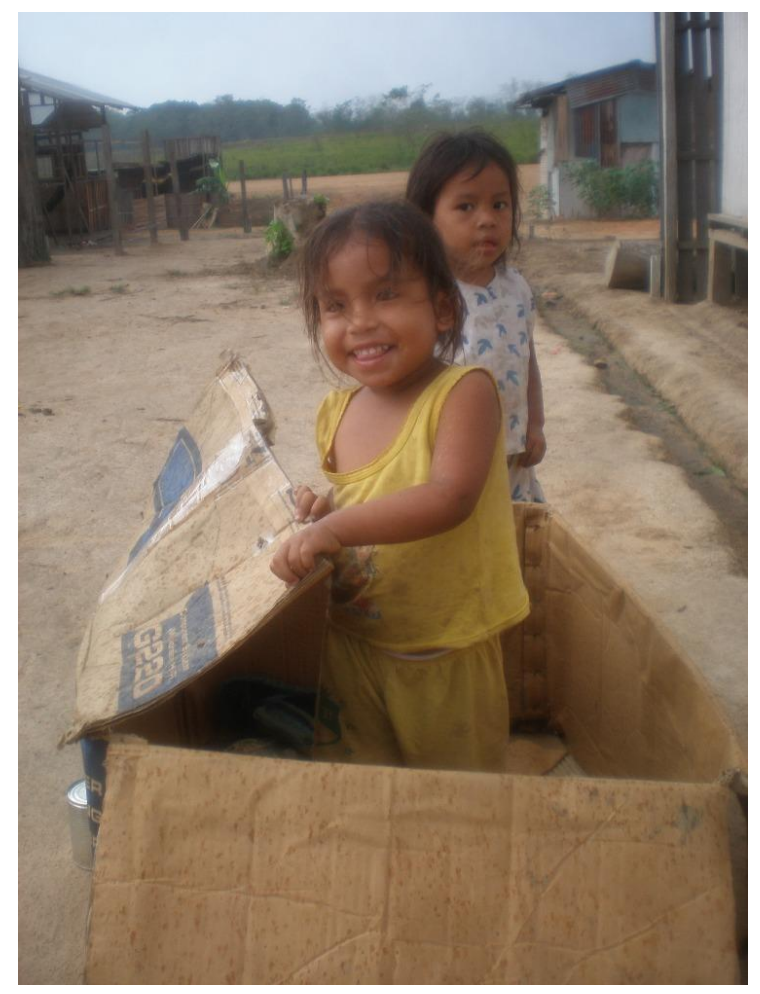

Foto 1. Zdravé dívenky z chudinské čtvrti Pucallpy. Jejich máma by měla sklízet obdiv. Obdivuhodná je za to, jak to v těchto podmínkách dokáže. Všimněte si prosím vznikající pouště v pozadí. Autor fotografií, Jiří Kmínek, není apokalyptik. Ale všímat bychom si toho měli.

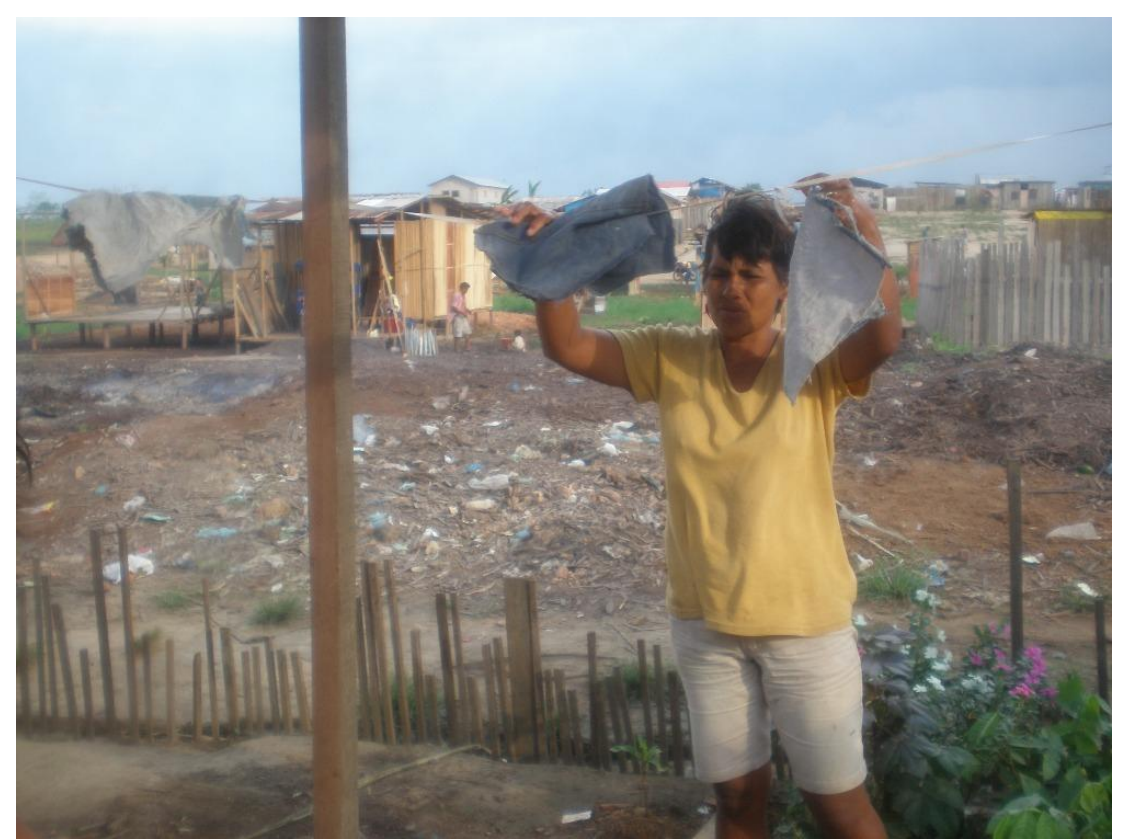

Foto 2. Maminka dívenek u svého domu věší prádlo. Odpadové hospodářství nula. Př́roda to ale umí tak, že infekční nemoci nijak v Amazonii nebují, jak by mohla fotka napovídat. Je tam spousta dalších, především fyzikálních faktorů, které infekce eliminují. 


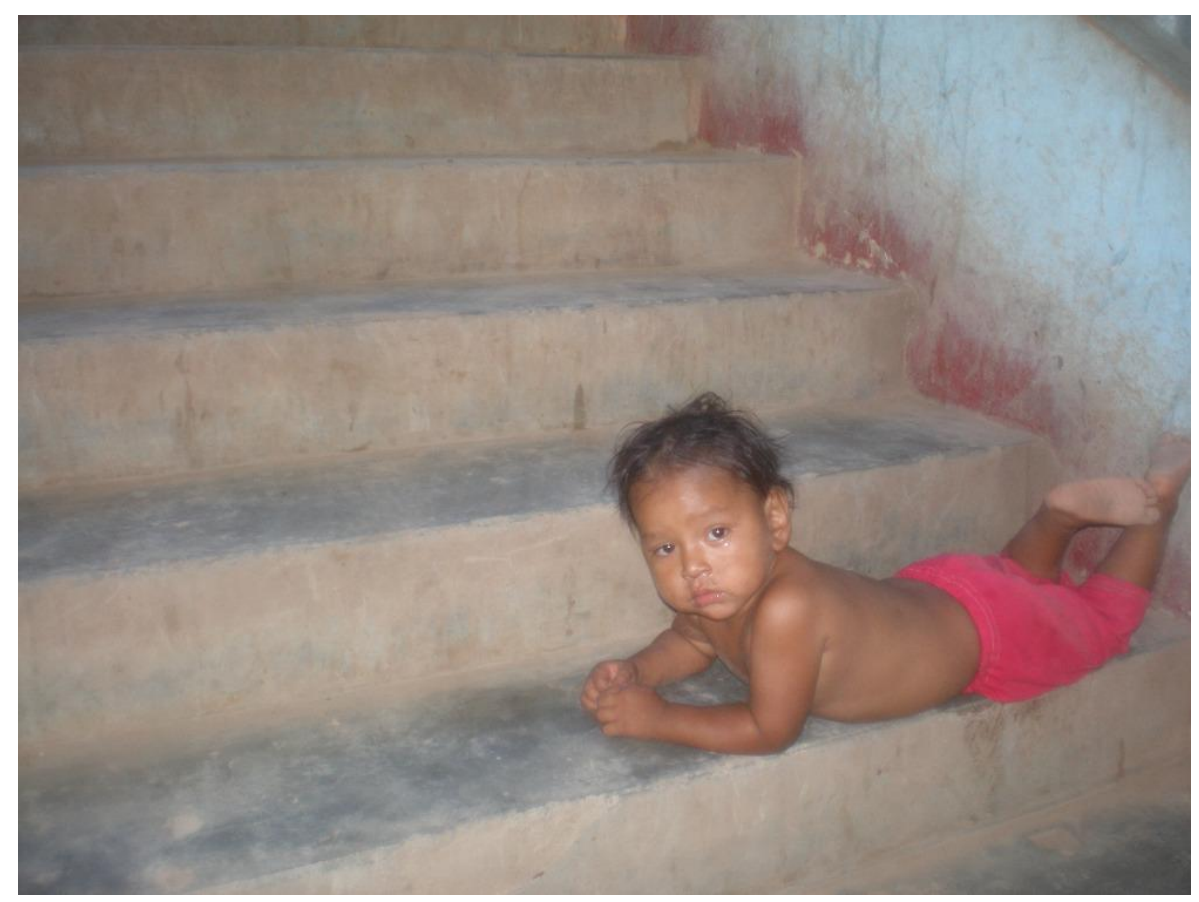

Foto 3. Nenechte se mýlit, tento zdánlivě tlustoučký chlapec je podvyživený. Jí jenom fariňu, což je drt' ze sušené juky. Chybí mu živočišné bílkoviny. Pozor, je to prvotřídní fotka.

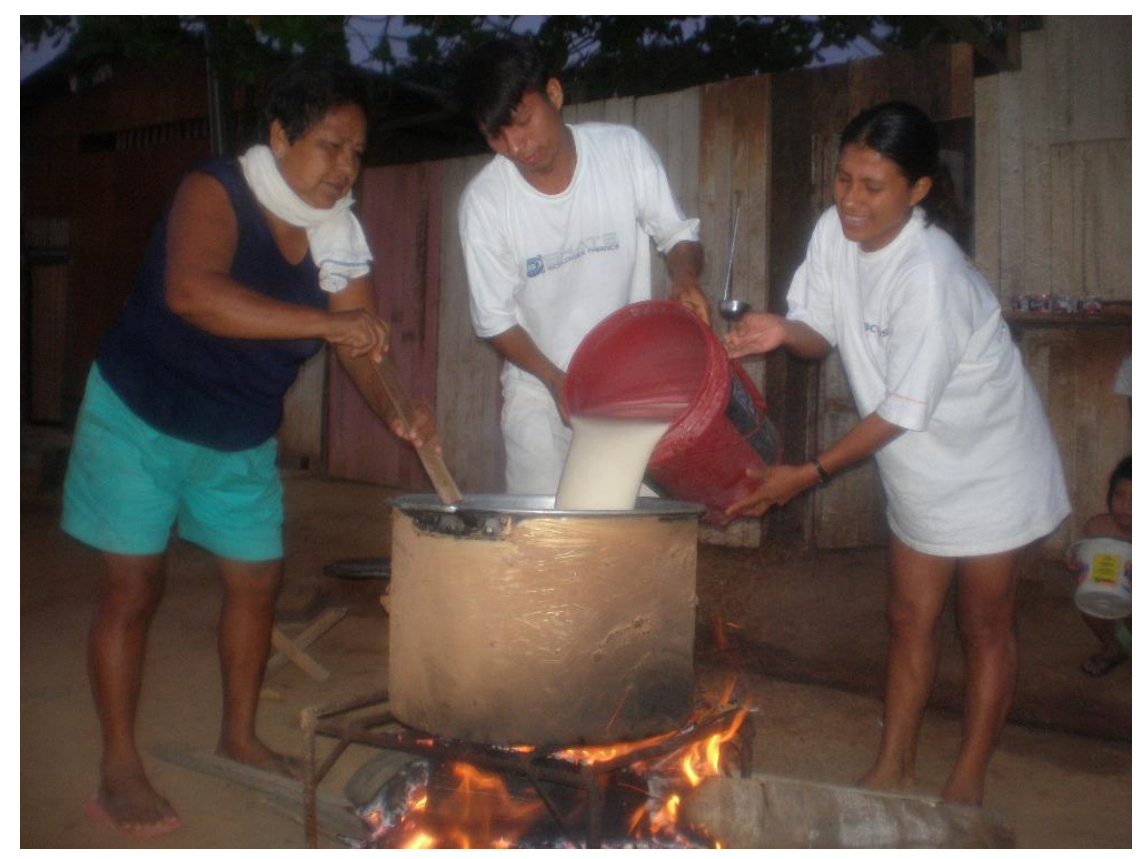

Foto 4. Brzy ráno začínáme vařit sušené mléko dětem. Je dotované peruánským státem. Problém je, že mléko není kontrolováno na slintavku a proto je výsledný produkt z mého pohledu nepoživatelný. Peruáncům to nevadí. 


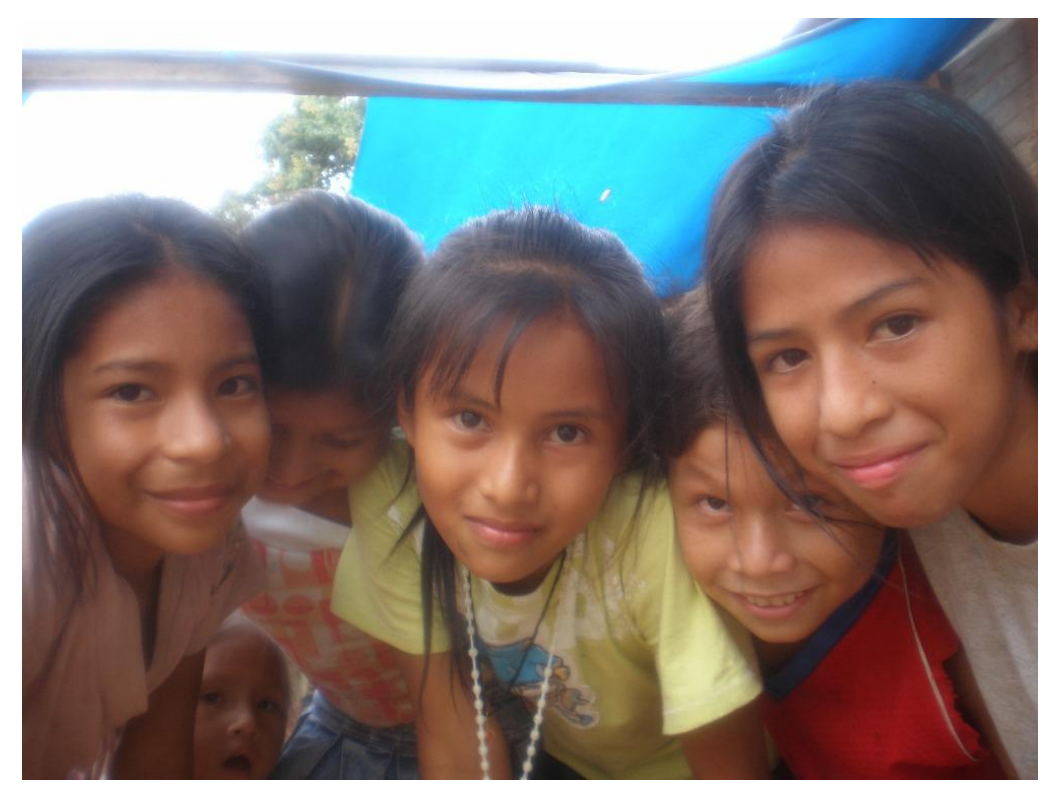

Foto 5. Pucallpské dívky, které mi na projektu Imagion Amazonia pomáhaly. OSN tomu říká "girl effect". Znamená to, že se zkrátka a jednoduše předá odpovědnost za DĚJE dívkám v tomto věku. A ony to suverénně všechno zvládají. Kluci to nedokáží. Já jsem to dělal již v roce 2007. O tom sousloví jsem se dozvěděl až ze stránek OSN v roce 2010. Mám roky náskok, jak je to u mne obvyklé (promiňte mi tu troufalost). Ale především: tak vzniká přirozený edukační řetězec. Malé děti, dívky $v$ pubescentním věku podvědomě se připravující na mateřství, jejich mámy, tety, babičky. Tak to má vypadat.



Foto 6. Stavba Imagionu s pomocí synů mé kolegyně Rosario Ramirez Panaijo. Kluci byli velmi ukáznění, šikovní a pozorní. Ted’ už jsou velcí a na univerzitách. Doufám a předpokládám, že jsou díky Rosario tak dobře vychováni, že se nezařadí mezi proslulé jihoamerické „machos". V Evropě je tento pojem používán s "legrací pod vousy". Já tento druh humoru nesdílím a ostře ho v dialozích s Evropany vymezuji. Machismus je totiž čistá, a pronikavě viditelná sociální patologie až kriminálního charakteru. 


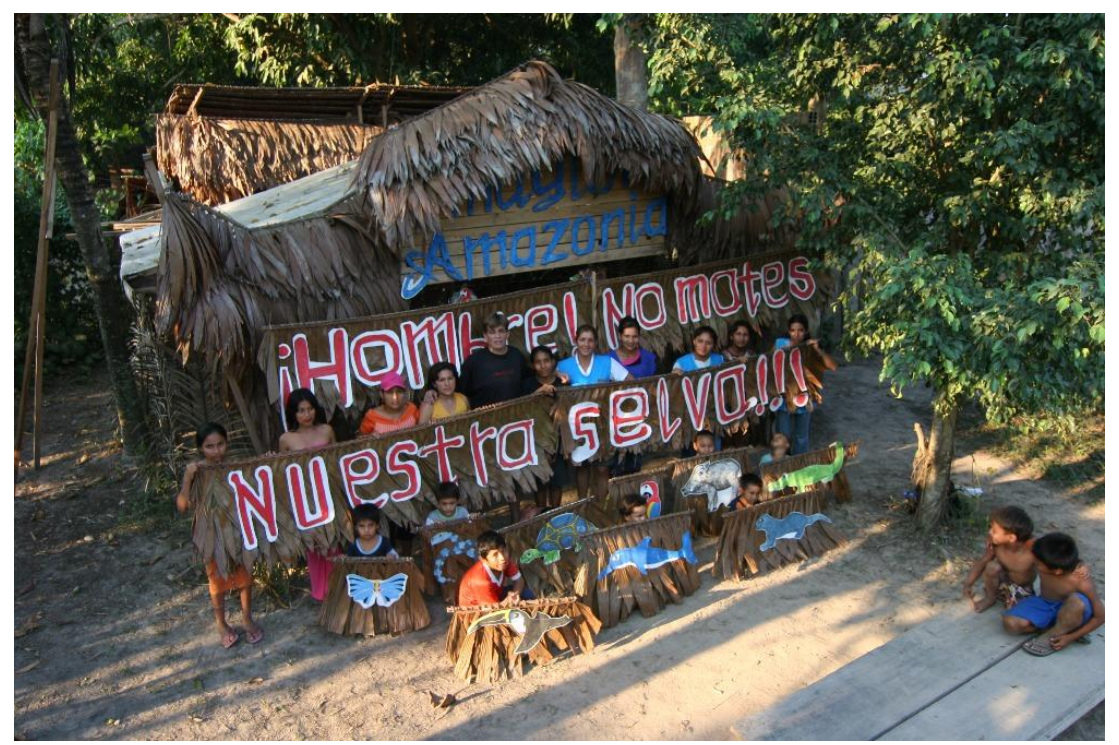

Foto 7. Otevření projektu Imagion Amazonia dětem. Velký nápis je: "Hombre, no mates nuestra selva!" a znamená v překladu přibližně „Chlapi, nelikvidujte naši džungli". Oslovení „Hombre", není už úplně spisovné a je pejorativní.

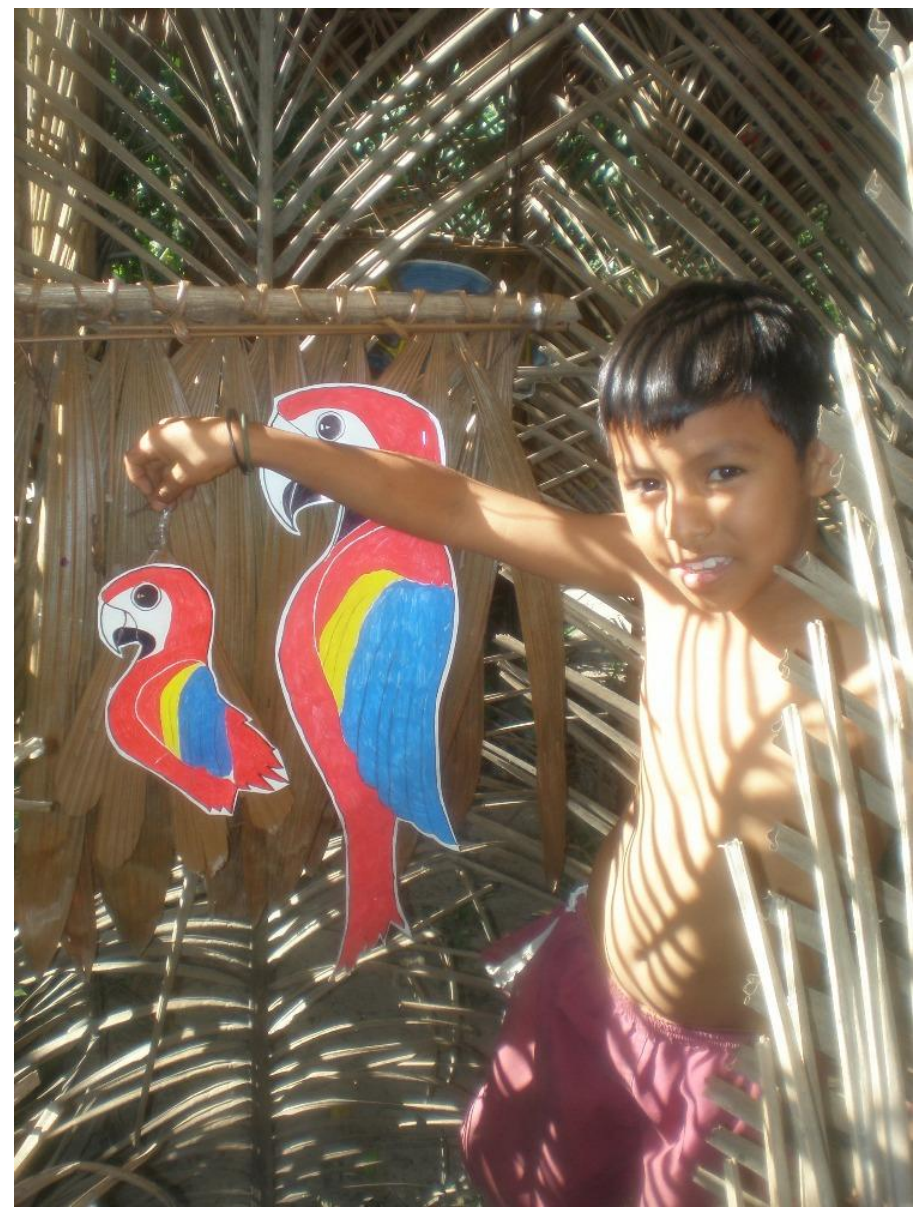

Foto 8. Chlapec v labyrintu nachází „guacamaya", papouška, který je pro Peruánce symbolem Amazonie. 


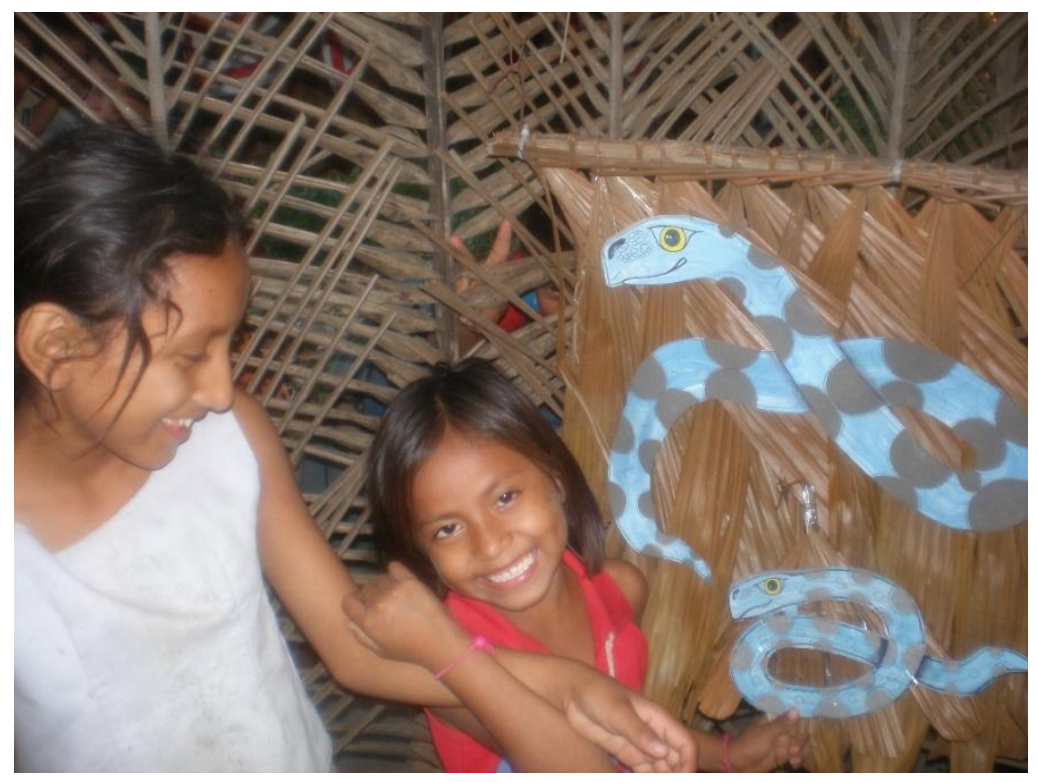

Foto 9 Dívenka s dívkou (girl effect) v labyrintu.

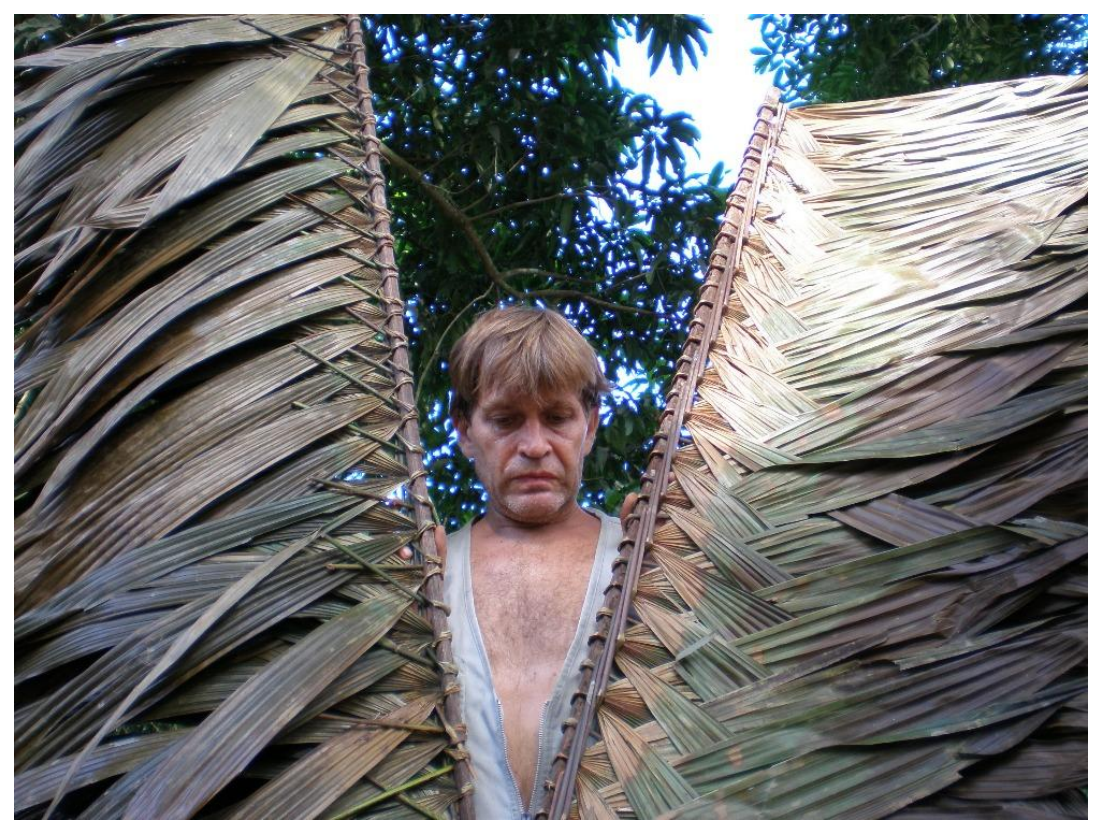

Foto 10. Zat́atě nespirituální a neezoterický $100 \%$ autor projektu Imagion Amazonia Jiří Kmínek na fotografii z roku 2007. Zde roztahuje křídla. Avšak nejsou to křídla, je to střešní krytina z listů křoviny irapay. Je velice pohledná, činí zvuk dopadajícího deště př́ijemným - na rozdíl od plechových krytin - a vydrží až 7 let. 